\title{
Investigation of Some Metals in Leaves and Leaf Extracts of Lippia javanica: Its Daily Intake
}

\author{
Kanda Artwell, Ncube France, and Kunsamala Florence \\ Department of Environmental Science, Bindura University of Science Education, Private Bag 1020, Bindura, Zimbabwe \\ Correspondence should be addressed to Kanda Artwell; alzkanda@gmail.com
}

Received 17 January 2017; Revised 9 May 2017; Accepted 30 May 2017; Published 11 July 2017

Academic Editor: Pam R. Factor-Litvak

Copyright (C) 2017 Kanda Artwell et al. This is an open access article distributed under the Creative Commons Attribution License, which permits unrestricted use, distribution, and reproduction in any medium, provided the original work is properly cited.

Consumption of plant extracts can be a source of essential elements or a route of human exposure to toxicants. Metal concentrations in leaves, leaf brew, and infusion of $L$. javanica collected from five sites were determined by atomic absorption spectrometry after acid and aqueous extraction. Estimated daily intakes of metals in extracts were compared with recommended dietary allowances. Total metal concentrations in leaves varied with sampling sites $(p<0.05)$ : $\mathrm{Mn}>\mathrm{Fe}>\mathrm{Cu}>\mathrm{Cr}>\mathrm{Pb}$ for sites SS2-SS5. The highest metal concentrations in leaves were recorded for SS3 (Cu: $15.32 \pm 4.53$ and Mn: $734.99 \pm 105.49$ ), SS5 (Fe: $210.27 \pm 17.17$ ), SS2 $(\mathrm{Pb}: 3.11 \pm 0.21)$, and SS4 $(\mathrm{Cr}: 4.40 \pm 0.75 \mathrm{mg} / \mathrm{kg})$. Leaf infusion appeared to release higher $\mathrm{Cu}$ and $\mathrm{Mn}$ concentrations in leaves across sites (Cu: 21.65; Mn: 28.01\%) than leaf brew (Cu: 11.95; Mn: 19.74\%). Lead was not detected in leaf extracts. Estimated dietary intakes of $\mathrm{Cr}, \mathrm{Cu}, \mathrm{Fe}$, and $\mathrm{Mn}$ were below recommended dietary allowances. A $250 \mathrm{ml}$ cup of leaf infusion contributed $0.30-1.18 \%$ $\mathrm{Cu}$ and $4.46-13.83 \% \mathrm{Mn}$ to the recommended dietary allowances of these elements per day. Lead did not pose any potential hazard when consumed in tea beverage made from brew and infusion of leaves of $L$. javanica.

\section{Introduction}

Natural and anthropogenic activities have increased metal concentrations in the environment to unprecedented toxic levels [1-3]. Since plants are capable of taking up metals from soil, the safety, quality, and effectiveness of natural products have become questionable [4]. For example, human dietary exposure to $\mathrm{Pb}$ in rice has been reported in previous studies $[5,6]$. The consumption of plant tissues may be an important route, not only for essential dietary trace elements but also for human exposure to toxic elements. Various adverse human health effects have been linked to ingestion of toxic metals [7-9]. The likelihood of developing symptoms of disease due to metal toxicity has been attributed to risk factors such as characteristics of the metal (concentration, form, dose, and toxicity) and individual level factors (social, health, behaviour, and physiology) $[8,10,11]$.

Lippia javanica (Burm F.) Spreng of the family Verbenaceae is a common woody shrub found in different soil types in most parts of central and southern Africa [12,13], tropical Africa, and central and southern Americas [14]. It grows in open veld, bush, and forest margins [12]. The chemistry, pharmacology, and uses of leaves of L. javanica are well documented [13-15]. Apart from its herbal applications, dried leaves of $L$. javanica are used as a tea alternate in routine diet in some parts of South Africa [12] and Zimbabwe. It appears that there is little information available for the concentration of metals in leaves of $L$. javanica and their potential contribution to human diet. There are no recommended quantities or procedures for making tea beverage using dried leaves of L. javanica as these vary with households. Information on acceptable levels of metals in leaves or the final brew and infusion extracts and metal contributions in the daily human diet is also not available. Such information is important to avoid deficient or excessive metal intakes.

The human body requires trace elements for healthy growth, development, and proper body functioning [16]. Studying their contribution to the human diet becomes very important because excessive or insufficient intake may cause various nutritional diseases. Chromium potentiates insulin action, influencing carbohydrate, lipid, and protein metabolism [17]. Chromium (III) is an essential element with low toxicity and rare deleterious effects of excessive intake [17]. Chromium (VI) is toxic and has respiratory, 
cardiovascular, gastrointestinal, hematological, hepatic, and neurological effects [11]. Copper is an essential element for the normal function of more than 30 enzymes, incorporated into metalloenzymes involved in haemoglobin formation, xenobiotic metabolism, carbohydrate metabolism, catecholamine biosynthesis, and antioxidant defence mechanism [18]. Deficiency of $\mathrm{Cu}$ in humans may induce anaemia, leukopenia, and osteoporosis [18]. Manganese is an activator and constituent of several enzymes which regulate lipid and carbohydrate metabolism, bone and tissue formation, and skeletal growth [19]. It is considered among the least toxic of trace elements when administered orally and excessive intake of $\mathrm{Mn}$ by ingestion is not a problem as the body regulates it homeostatically [17]. Iron is an essential element in haemoglobin, myoglobin, ferredoxins, and several enzymes active in porphyrin synthesis, transport of oxygen, and normal functioning of the immune system [20]. Deficiency in Fe causes anaemia. Infants, children, and pregnant mothers are the most susceptible to anaemia, an Fe deficiency [20]. Lead is a xenobiotic toxicant which can accumulate in body organs (gastrointestinal tract, and kidneys) and the central nervous system leading to poisoning [21-24]. Children are most vulnerable to $\mathrm{Pb}$ poisoning due to neurological, neurobehavioural, and developmental effects [22]. Lead has been classified as a category $2 \mathrm{~B}$ carcinogen (possible carcinogenicity to humans) by the IARC [25] but with inadequate carcinogenicity evidence for humans.

The current study determined (1) total concentrations of metals ( $\mathrm{Cr}, \mathrm{Cu}, \mathrm{Fe}, \mathrm{Mn}$, and $\mathrm{Pb}$ ) in leaves of $L$. javanica by acid digestion and (2) concentrations of elements in brew and infusion extracts. Also, contributions of tea brew and infusion made from leaves of $L$. javanica to dietary intake of metals were determined. The study was premised on the hypotheses that sampling sites influenced metal concentrations in $L$. javanica leaves. The solubility of a metal was assumed to be dependent on the method of extraction and the specific metal.

\section{Materials and Methods}

2.1. Sampling, Sample Preparation, and Analysis. Seven sites were purposively selected for sampling leaves of L. javanica: along sides of a railway line (SS1), busy road side (SS2), at a municipal solid waste dumpsite (SS3), in an informal light industrial area (SS4), around a sewage outfall (SS5), grassland (SS6), and a natural forest (SS7). Sampling was done in Marondera, Zimbabwe (lat. 018.18527 and long. 031.55193). Healthy green leaves without signs of parasitic herbivory or disease were sampled from three L. javanica plants at each site after the flowering stage. The leaves were cleaned with deionised water. They were put into polythene bags and shipped to the laboratory and air-dried for seven days. Three air-dried samples from each site were separately ground (SM-450-C grinder) and sieved (nylon $0.425 \mathrm{~mm}$ ). Sample preparation and analysis were done following procedures described by Soomro et al. [16] with minor modifications for boiling time and hot water extraction volumes. For the determination of total metal concentration, three powdered samples (2 g each) were weighed into Teflon vessels. A $12 \mathrm{ml}$ concentrated acid mixture $\left(69 \% \mathrm{HNO}_{3}: 70 \% \mathrm{HClO}_{4} ; 3: 1 \mathrm{v} / \mathrm{v}\right)$ was used for digestion over a sand bath in a fume hood until it became clear. The cooled digests were filtered into a $100 \mathrm{ml}$ volumetric flask and made to the mark with $5 \%$ $\mathrm{HNO}_{3}$. For hot water extraction, three similar powdered leaf samples from the same site were each separately added to boiling distilled water $(250 \mathrm{ml})$ for five minutes over a hot plate, cooled, and filtered (Whatman No. 42) under gravity.

To determine the fraction of element extracted by infusion of leaf samples in boiling water, three $2 \mathrm{~g}$ leaf samples were separately added to each of a third set of three conical flasks in which $250 \mathrm{ml}$ of boiling distilled water were added. They were allowed to stand for 5 minutes, cooled, filtered under gravity, and evaporated to near dryness. The residues were acid-digested and the final volume adjusted as described above. Ten sample solutions were analysed for their elemental concentrations alongside a reagent blank solution using flame atomic absorption spectrometry. The digestion procedure was validated by using spike-and-recovery experiments for the metals. In this procedure, a laboratory sample was spilt into four replicate aliquots. For the analysis of total metal concentration, a homogenised sample of leaf powder was used. Evaporation residues of leaf brew and infusion were each separately used for validating the digestion procedure. An analyte of known concentration was separately added to three aliquots of each laboratory sample. The four samples (including the unspiked aliquot) were digested and analysed following the general procedure. Element recovery (\%) was determined as the difference between the spiked and unspiked samples divided by the spike sample added, expressed as a percentage [27]. The method detection limit (MDL) was determined by running ten method blank solutions and expressing it as three times the mean standard deviation of blank solutions [27].

Concentrations of elements were determined by extrapolation from a calibration graph developed from working standards made by serial dilutions of appropriate stock solutions. The spectrometer (Thermo Scientific model iCE 3000 series) was optimised for element analysis following instructions of the manufacturer (Table 1). Analyte samples and blanks were aspirated into the instrument. Standard solutions were rerun after every batch of 10 samples to check and correct any instrumental drift. Estimated daily intake (EDI) of trace element was determined and compared with recommended dietary allowances (RDA) following procedures described by Brzezicha-Cirocka et al. [28]. This was done because of lack of information of maximum allowable concentrations of trace elements in tea leaves. The mass of leaves of L. javanica used to make the beverage brew and infusions ( $2 \mathrm{~g}$ ) was of commercial tea bags (Quickbrew ${ }^{\mathrm{TM}}$ ) commonly available in supermarkets. The volume of tea consumed by an individual $(250 \mathrm{ml})$ was of tea cups used in the study area.

2.2. Statistical Analysis. Data were subjected to One-Way ANOVA to determine any significant differences in the concentration of metals extracted by three treatments of leaves of L. javanica sampled from seven sites. Where differences were significant, pairwise comparisons were conducted using LSD post hoc. Estimated daily intake values for trace elements 
TABLE 1: Operational conditions of the atomic absorption spectrometer (FAAS Thermo Scientific model iCE 3,000 series) used for the analysis of some metals in L. javanica leaves and aqueous leaf extracts. The flame was air acetylene ${ }^{\mathrm{a}}$.

\begin{tabular}{|c|c|c|c|c|c|}
\hline Metal & $\begin{array}{c}\text { Wavelength } \\
(\mathrm{nm})\end{array}$ & $\begin{array}{c}\text { Band pass } \\
(\mathrm{nm})\end{array}$ & $\begin{array}{c}\text { Lamp current } \\
(\mathrm{mA})\end{array}$ & $\begin{array}{c}\text { Fuel flow } \\
\text { rate }(\mathrm{L} / \mathrm{min})\end{array}$ & $\begin{array}{c}\text { Correlation } \\
\text { coefficient }\left(R^{2}\right)\end{array}$ \\
\hline $\mathrm{Cr}$ & 357.9 & 0.5 & 10.00 & 4.2 & 0.9978 \\
\hline $\mathrm{Cu}$ & 324.8 & 0.5 & 7.50 & 1.1 & 0.9992 \\
\hline $\mathrm{Fe}$ & $248.3^{*}$ & 0.2 & 11.25 & 0.9 & 0.9988 \\
\hline $\mathrm{Mn}$ & $279.5^{*}$ & 0.2 & 7.50 & 1.1 & 0.9971 \\
\hline $\mathrm{Pb}$ & $217.0^{*}$ & 0.5 & 7.50 & 0.9 & 0.9985 \\
\hline
\end{tabular}

${ }^{\mathrm{a}}$ For Cr the flame was $\mathrm{N}_{2} \mathrm{O}-\mathrm{C}_{2} \mathrm{H}_{2}$.

${ }^{*}$ With $\mathrm{D}_{2}$ Quadline background correction.

TABLE 2: Mean concentrations (mean $\pm \mathrm{SD}, \mathrm{mg} / \mathrm{kg}, \mathrm{DW}, n=3$ ), element recoveries (\%), RSD (\%), and LOD for metals in leaf samples of $L$. javanica $(n=7)$.

\begin{tabular}{|c|c|c|c|c|c|c|}
\hline Element & Aliquot & Spiked sample & spike & $\%$ recovery & $\% \mathrm{RSD}$ & $\mathrm{LOD}(\mathrm{mg} / \mathrm{kg})$ \\
\hline $\mathrm{Cu}(\mathrm{T})$ & 10.28 & $11.50 \pm 0.80$ & 2.10 & $92.89 \pm 1.12$ & 6.96 & 0.230 \\
\hline $\mathrm{Cu}(\mathrm{I})$ & 3.36 & $4.98 \pm 0.35$ & 2.10 & $91.21 \pm 1.46$ & 7.03 & 0.230 \\
\hline $\mathrm{Fe}(\mathrm{T})$ & 104.44 & $126.26 \pm 7.23$ & 20.80 & $102.41 \pm 2.20$ & 5.73 & 1.250 \\
\hline $\operatorname{Mn}(\mathrm{T})$ & 86.25 & $96.51 \pm 6.34$ & 17.20 & $94.26 \pm 1.80$ & 6.57 & 1.540 \\
\hline $\mathrm{Mn}(\mathrm{B})$ & 39.71 & $52.77 \pm 4.27$ & 17.20 & $92.72 \pm 1.39$ & 8.09 & 0.120 \\
\hline $\mathrm{Pb}(\mathrm{B})$ & 0.00 & $2.34 \pm 0.11$ & 2.52 & $92.73 \pm 0.23$ & 4.70 & 0.120 \\
\hline $\mathrm{Cr}(\mathrm{I})$ & 0.63 & $1.57 \pm 0.06$ & 1.00 & $96.32 \pm 0.62$ & 3.83 & 0.188 \\
\hline
\end{tabular}

T: total metal concentration, B: leaf brew, and I: leaf infusion.

were expressed as percent fractions of recommended dietary allowances (DRA) values. All analyses performed were considered significant at $95 \%$ level of confidence.

2.3. Quality Control Procedures. Concentrated acids used were ACS-grade reagents (Merck, Germany). Triplicate samples were used and each was measured three times. Reagent blanks were run alongside laboratory samples. Instrument recalibration for drift was done by stepwise correction [27] using prepared standards after a batch of 10 analyte samples.

\section{Results and Discussion}

3.1. Total Concentrations of Elements in Leaf Samples of $L$. javanica. Table 2 shows that element recoveries from spiked samples were from $91.21 \pm 1.46$ to $102.41 \pm 2.20 \%$. The percentage Relative Standard Deviation (\% RSD) values were $<10 \%$. Table 3 shows the concentrations of $\mathrm{Cr}, \mathrm{Cu}, \mathrm{Fe}, \mathrm{Mn}$, and $\mathrm{Pb}$ in dried leaf samples of $L$. javanica from seven sampling sites. Total concentrations (acid-digested) of $\mathrm{Cr}$ and $\mathrm{Pb}$ were not detected in leaf samples from sampling sites SS1, SS6, and SS7. Concentrations recorded for $\mathrm{Cu}, \mathrm{Fe}$, and $\mathrm{Mn}$ at SS6 and SS7 were not significantly different $(p>0.05)$. Highest total concentrations of elements were recorded at sites SS2 $(\mathrm{Pb})$, SS3 $(\mathrm{Cu}$ and $\mathrm{Mn}), \mathrm{SS} 4(\mathrm{Cr})$, and SS5 $(\mathrm{Fe})$ while lowest values were recorded at sites SS6 and SS7 for elements studied (Table 3). Significant differences in total concentrations of elements were observed for $\mathrm{Cr}$ (SS1-SS4), Fe and Mn (SS1-SS5), and $\mathrm{Pb}(\mathrm{SS} 2-\mathrm{SS} 5)(p<0.05)$. Mean total concentrations of trace elements in leaves of $L$. javanica from seven sampling sites decreased in the order: $\mathrm{Mn}>\mathrm{Fe}>\mathrm{Cu}>\mathrm{Pb}>\mathrm{Cr}$.

The presence of trace elements in leaves of Lippia javanica reveals that the plant can accumulate them. Undetectable amounts of elements in samples from SS6 (grassland) and SS7 (natural forest) may suggest no point sources except for background concentrations and diffuse source contributions such as atmospheric deposition and surface runoff. Chromium was found the highest in leaf samples from the light industrial area (SS4). High concentrations of $\mathrm{Cr}$ were reported in plants growing in high $\mathrm{Cr}$ containing soils, for example, near ore deposits, Cr-emitting industries, and soils fertilised with sewage sludge [28]. Copper and Mn were the highest in leaf samples collected from the municipal dumpsite (SS3). Common sources of $\mathrm{Cu}$ are waste dumps, domestic wastewater, landfills, agricultural use, wood production, and combustion of fuels [20]. Manganese is commonly released into the environment from steel manufacturing, fireworks, dry-cell batteries, fertilisers, and paints [19].

Iron is ubiquitous in the natural environment in elevated concentrations. Its many applications may elevate concentrations in the soil, finally in the plant. Sewage contains many elements whose availability to plants is limited by many factors including complexity in composition. Lead was found to be the highest in leaves sampled along the busy road (SS2). This may not be expected considering that leaded gasoline has been banned [21]. It may be assumed that leaded gasoline is still being used especially in developing countries. According to ATSDR [21] the highest concentrations of $\mathrm{Pb}$ were reported in plants growing near $\mathrm{Pb}$ mining sites, storage batteries, 


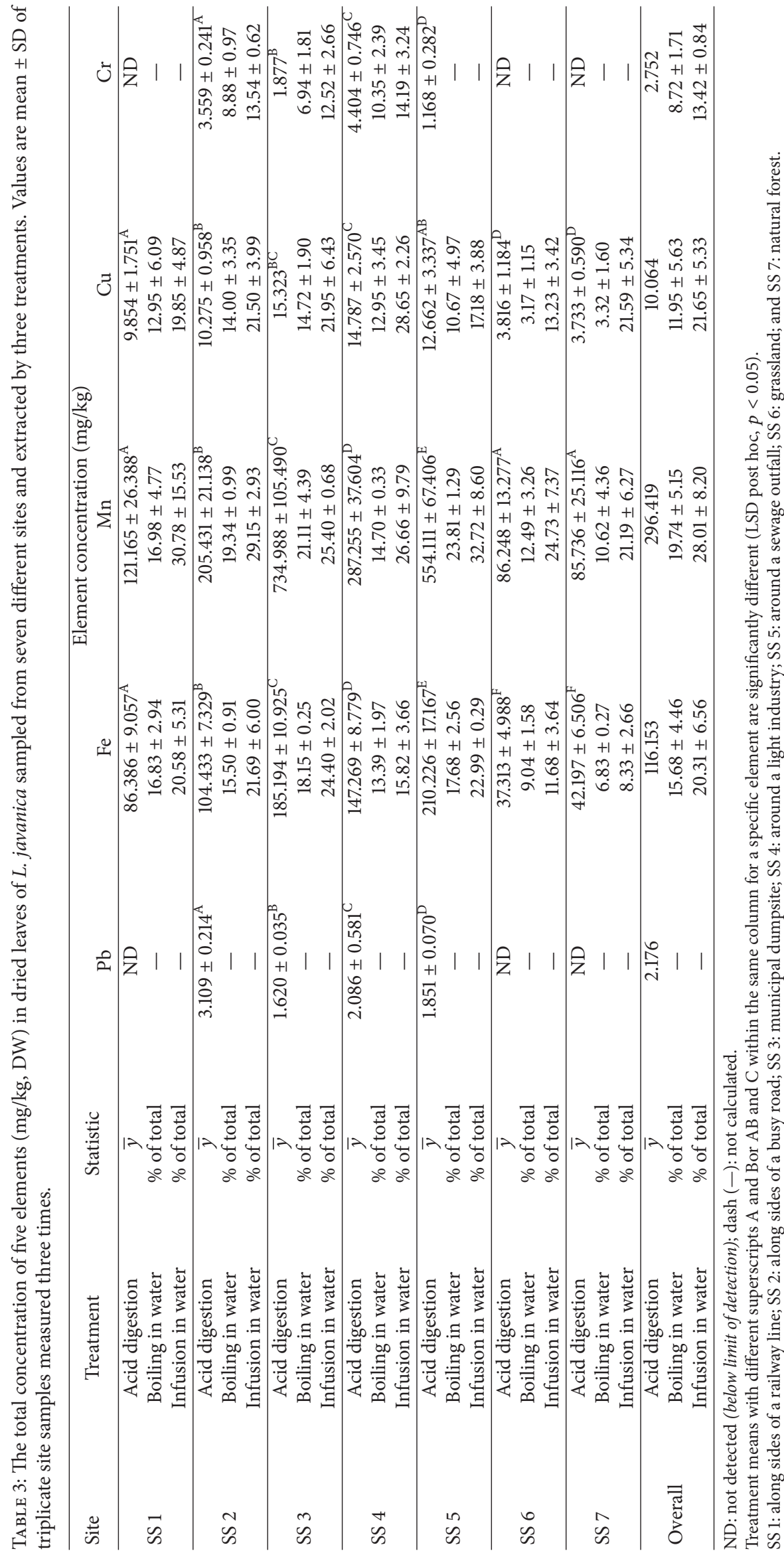


spoil disposal areas, sewage sludge, and areas affected by automobile traffic.

It appears currently that there are no studies reporting on concentrations of heavy metals in leaves, leaf brew, and infusion extracts of $L$. javanica, save for Mahlangeni et al. [29], South Africa, where the plant is extensively used as herbal infusion and tea alternative. Most related studies were done on tea products of Camellia sinensis bought from market places worldwide [16, 30-33]. Mahlangeni et al. [29] showed that $L$. javanica leaves contained site-dependent metal concentrations from 10 sites in the decreasing order: $\mathrm{Fe}>\mathrm{Mn}>$ $\mathrm{Cu}>\mathrm{Cr}>\mathrm{Pb}$ compared to $\mathrm{Mn}>\mathrm{Fe}>\mathrm{Cu}>\mathrm{Pb}>\mathrm{Cr}$ from this study. The highest total metal concentrations reported were about $2.6(\mathrm{Cr}), 9.0(\mathrm{Cu}), 800(\mathrm{Fe})$, and $1.25 \mathrm{mg} / \mathrm{kg}$ $(\mathrm{Pb})$. Observed differences in elemental concentrations for leaf samples in these two studies could be due to factors that influence their uptake such as soil characteristics and properties of elements [21, 23]. Total metal concentrations in leaves of Camellia sinensis were observed to increase with increasing age of the plant [31]. However, postflowering stage and increasing distance from a point source of metal were observed to reduce metal concentration in leaves of Salvia officinalis, a herbal tea [34].

3.2. Proportion of Elements Extracted from Leaves of $L$. javanica by Leaf Brew and Infusion. Table 3 also shows water extractable fractions of elements from leaves of $L$. javanica by leaf brew and infusion over five minutes. Lead was not detected at all sites by the two treatment methods. Chromium was detected only at SS2 and SS4 in leaf brew and at SS2, SS3, and SS4 in leaf infusion in significantly different concentrations $(p<0.05)$. Leaf infusion appeared to extract a greater proportion of $\mathrm{Mn}$ and $\mathrm{Cu}$ than brewing. The highest proportions of elements in leaf infusions were recorded for sites SS4 (Cr: 22.71; Cu: 28.65), SS3 (Fe: 24.40), and SS5 (Mn: 32.72\%). The overall mean extraction of elements by leaf infusion across all sites followed the decreasing trend $\mathrm{Mn}>\mathrm{Cu}>\mathrm{Fe}>\mathrm{Cr}>\mathrm{Pb}$. Leaf brew of L. javanica had mean element extractions of $14.03(\mathrm{Cr}), 11.95(\mathrm{Cu}), 15.68(\mathrm{Fe})$, and $19.74 \%(\mathrm{Mn})$. Mahlangeni et al. [29] reported extraction percentages of 37-68.8 (Pb), 23.1-28.7 (Fe), 21.5-48.8 (Cu), and $71.8-93.9 \%(\mathrm{Cr})$ in leaf brew after 10 minutes. These values are higher than both extractions from our study. Variations could be explained by differences in boiling time, method of brewing, and brand of tea which were shown to influence the degree of element extraction from the total content [16, 30]. ATSDR [19] considers many forms of Mn as water soluble. This could explain the high proportion of metal release from the leaf into aqueous solution. The solubility of $\mathrm{Pb}$ in water is a function of $\mathrm{pH}$, hardness, salinity, and presence of humic material [21]. The observation that $\mathrm{Mn}$ and $\mathrm{Cu}$ appeared to be released more into the infusion than brew extracts was explained for Camellia sinensis in terms of their potential for chelation with tannins and tannic acid which exudes on boiling (brew) such that when chelates precipitate, element content decreases [35]. In separate studies, little or no $\mathrm{Pb}$ was detected in leaves, made tea, and infusions from Camellia sinensis, common tea $[32,35,36]$. Camellia sinensis has been shown to release high concentrations of $\mathrm{Mn}$ in made tea and its infusions $[28,30,36]$.

The general trend on the content of metals in hot water extracts of Camellia sinensis reported by Soomro et al. [16] was $\mathrm{Mn}>\mathrm{Fe}>\mathrm{Cr}>\mathrm{Cu}>\mathrm{Pb}$. This is slightly different from our findings $(\mathrm{Mn}>\mathrm{Cu}>\mathrm{Fe}>\mathrm{Cr}>\mathrm{Pb}$ ) for leaf infusion of $L$. javanica. In most tea infusion studies, it has been observed that distilled water is used for elemental extraction [30, 32]. However, in most rural communities where plants are exploited for various purposes, water is of marginal quality with various levels of elements. Water chemistry may influence the final concentrations of elements in the tea brew and infusions, consequently the final dietary intake of elements.

3.3. Estimated Daily Intake of Trace Elements. Table 4(a) shows the estimated dietary intake of trace elements by consuming of $250 \mathrm{ml}$ tea beverage made from brew extracts of $2 \mathrm{~g}$ of dried leaves of $L$. javanica for seven sites. Table $4(\mathrm{~b})$ shows the same information for leaf infusion. These data are shown against recommended dietary allowances of each element for a specified age group. Table 5 shows the percent contribution of estimated intake of elements from consuming $250 \mathrm{ml}$ of leaf brew and its infusion to the recommended daily dietary allowance of an element. Results suggest that all elements contributed a greater fraction to the RDA from the infusion extract across all age groups and special considerations (pregnancy and lactation) than leaf brew. Leaf extracts from $L$. javanica appear to contribute very little to the daily metal intake with respect to $\mathrm{Fe}$ and $\mathrm{Cu}$ whose percentages were less than unity, except for the infusion where $\mathrm{Cu}$ contributed $1.18 \%$ to children (1-3 years). Consuming one cup of $L$. javanica tea brew contributes 4.50-9.75 while the leaf infusion extracts $4.46-13.83 \%$ of the dietary Mn allowance per day. This contribution will increase with the number of cupfuls consumed. The similar cupful of extracts would contribute between 0.67-2.72 (from brew) and 1.11-4.55\% (infusion) $\mathrm{Cr}$ to the RDA. Results suggest that $L$. javanica may have the potential to contribute significantly to the daily intake of $\mathrm{Mn}$ and $\mathrm{Cr}$. Values are more pronounced for children who are the most susceptible to elemental toxicity and deficiency effects. Dietary reference standards are important for planning for meals and to educate consumers on deciding what food to eat and how much. Diet assessments assist in food safety which includes regulation, monitoring, education, and counselling [26].

\section{Conclusions}

The concentrations of $\mathrm{Cr}, \mathrm{Cu}, \mathrm{Fe}, \mathrm{Mn}$, and $\mathrm{Pb}$ in leaves, leaf brew, and infusion extracts of the tea alternate, $L$. javanica collected from seven sites, were determined. The study showed that the dietary contribution of $\mathrm{Cu}, \mathrm{Cr}, \mathrm{Fe}$, and $\mathrm{Mn}$ from the consumption of tea beverage was higher in the leaf infusion than the brew of L. javanica. However, leaf extracts appear to have very little contribution to toxic $\mathrm{Pb}$ dietary intake. Estimated daily intakes of studied metals were within recommended dietary intake values. Exposure to $\mathrm{Pb}$ through consuming tea beverage made from leaf brew and infusion of $L$. javanica collected from the seven sites did 

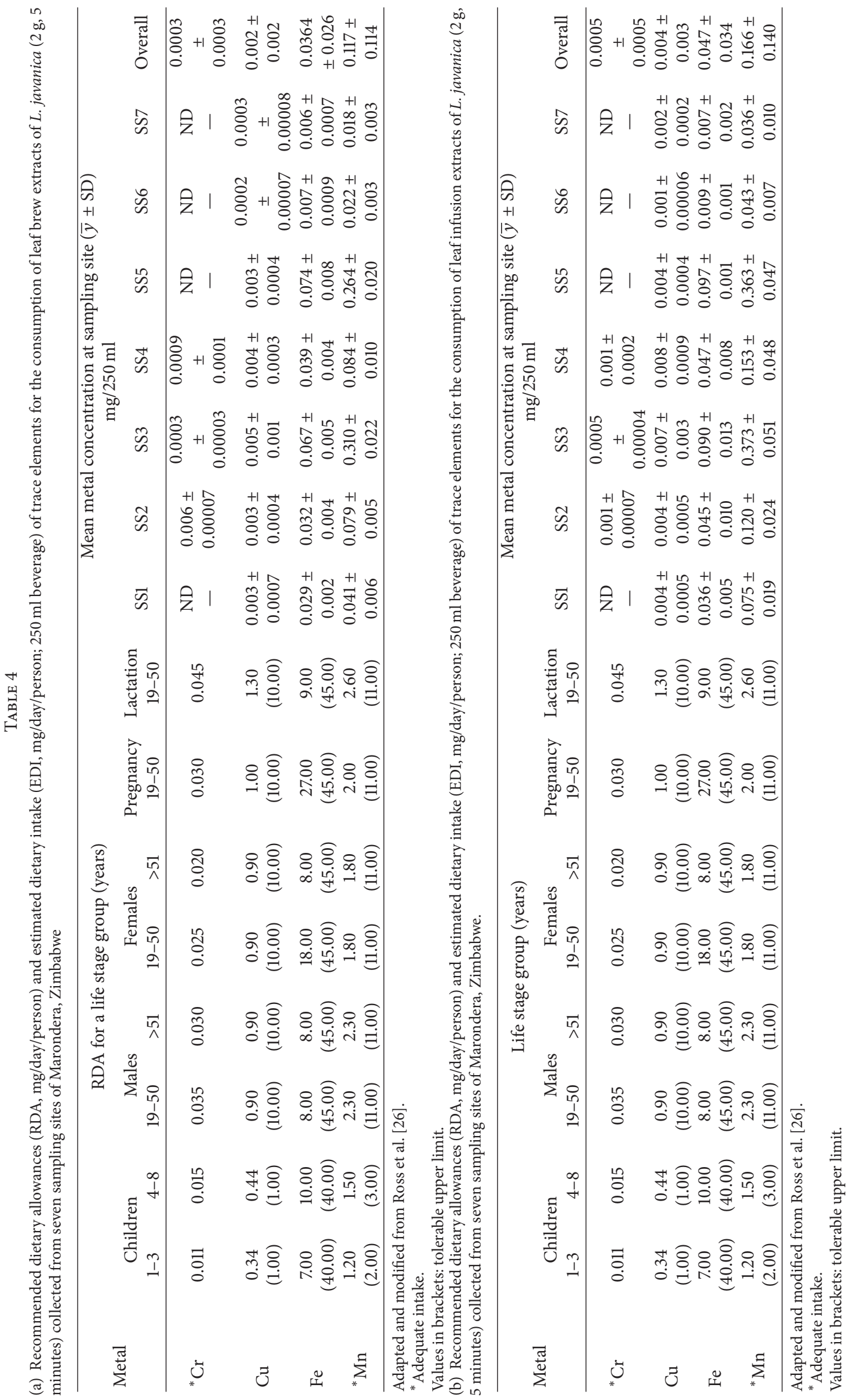


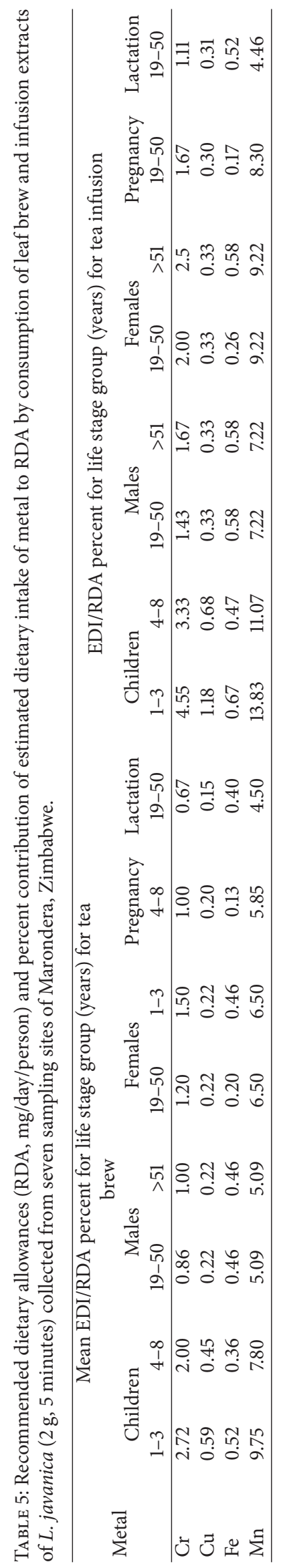


not constitute a health risk to the local population. Infusion leaf extracts of L. javanica may be an important source of $\mathrm{Cr}$ and $\mathrm{Mn}$ for daily dietary requirement of essential metals considering that tea generally forms part of a daily diet for most people. However, long term studies on dietary exposure to toxic metals through tea made from L. javanica growing in contaminated environments may be needed to safeguard human health.

\section{Conflicts of Interest}

The authors declare that there are no conflicts of interest regarding the publication of this paper.

\section{References}

[1] L. Jia, W. Wang, Y. Li, and L. Yang, "Heavy metals in soil and crops of an intensively farmed area: A case study in Yucheng City, Shandong Province, China," International Journal of Environmental Research and Public Health, vol. 7, no. 2, pp. 395-412, 2010.

[2] G. U. Chibuike and S. C. Obiora, "Heavy metal polluted soils: effect on plants and bioremediation methods," Applied and Environmental Soil Science, vol. 2014, Article ID 752708, 12 pages, 2014.

[3] R. Nazir, M. Khan, M. Masab et al., "Accumulation of heavy metals $(\mathrm{Ni}, \mathrm{Cu}, \mathrm{Cd}, \mathrm{Cr}, \mathrm{Pb}, \mathrm{Zn}, \mathrm{Fe})$ in the soil, water and plants and analysis of physico-chemical parameters of soil and water collected from Tanda Dam Kohat," Journal of Pharmaceutical Sciences and Research, vol. 7, no. 3, pp. 89-97, 2015.

[4] R. Singh, N. Gautam, A. Mishra, and R. Gupta, "Heavy metals and living systems: an overview," Indian Journal of Pharmacology, vol. 43, no. 3, pp. 246-253, 2011.

[5] M. A. Zazouli, M. Shorkzadeh, S. Fathi, and H. Izanlo, "Cadmium content in rice and its daily intake in Ghaemshahr region of Iran," African Journal of Biotechnology, vol. 7, no. 20, pp. 36893692, 2008.

[6] M. A. Zazouli, A. M. Bandpei, M. Ebrahimi, and H. Izanloo, "Investigation of cadmium and lead contents in iranian rice cultivated in babol region," Asian Journal of Chemistry, vol. 22, no. 2, pp. 1369-1376, 2010.

[7] R. K. Sharma and M. Agrawal, "Biological effects of heavy metals: an overview," Journal of Environmental Biology, vol. 26, no. 2, pp. 301-313, 2005.

[8] A. L. Oliveira Da Silva, P. R. G. Barrocas, S. Do Couto Jacob, and J. C. Moreira, "Dietary intake and health effects of selected toxic elements," Brazilian Journal of Plant Physiology, vol. 17, no. 1, pp. 79-93, 2005.

[9] M. Jaishankar, T. Tseten, N. Anbalagan, B. B. Mathew, and K. N. Beeregowda, "Toxicity, mechanism and health effects of some heavy metals," Interdisciplinary Toxicology, vol. 7, no. 2, pp. 6072, 2014.

[10] E. M. Alissa and G. A. Ferns, "Heavy metal poisoning and cardiovascular disease," Journal of Toxicology, vol. 2011, Article ID 870125, 21 pages, 2011.

[11] P. B. Tchounwou, C. G. Yedjou, A. K. Patlolla, and D. J. Sutton, "Heavy metal toxicity and the environment," in Molecular, Clinical and Environmental Toxicology, vol. 101, pp. 133-164, Springer, Basel, Switzerland, 2012.

[12] L. R. Lou-Nita, Lippia Javanica, National Biodiversity Institute, Durban, South Africa, 2004.
[13] A. M. Viljoen, S. Subramoney, S. F. V. Vuuren, K. H. C. Başer, and B. Demirci, "The composition, geographical variation and antimicrobial activity of Lippia javanica (Verbenaceae) leaf essential oils," Journal of Ethnopharmacology, vol. 96, no. 1-2, pp. 271-277, 2005.

[14] M. E. Pascual, K. Slowing, E. Carretero, D. S. Mata, and A. Villar, "Lippia: traditional uses, chemistry and pharmacology: a review," Journal of Ethnopharmacology, vol. 76, no. 3, pp. 201214, 2001.

[15] E. A. Shikanga, S. Combrinck, and T. Regnier, "South African Lippia herbal infusions: total phenolic content, antioxidant and antibacterial activities," South African Journal of Botany, vol. 76, no. 3, pp. 567-571, 2010.

[16] M. T. Soomro, E. Zahir, S. Mohiuddin, A. N. Khan, and I. I. Naqvi, "Quantitative assessment of metals in local brands of tea in Pakistan," Pakistan Journal of Biological Sciences, vol. 11, no. 2, pp. 285-289, 2008.

[17] WHO, Trace Elements in Human Nutrition and Health, World Health Organisation, Geneva, Switzerland, 1996.

[18] ATSDR, Toxicological Profile for Copper, US Department of Health and Human Services, Public Health and Human Services, Centre for Disease Control, Atlanta, Ga, USA, 2004.

[19] ATSDR., Toxicological Profile for Manganese, US Department of Health and Human Services, Public Health and Human Services, Centre for Disease Control, Atlanta, Ga, USA, 2012.

[20] WHO/FAO, Vitamin and Mineral Requirements in Human Nutrition, World Health Organisation/Food and Agricultural Organisation, Geneva/Rome, 2nd edition, 2004.

[21] ATSDR, Toxicological Profile for Lead, US Department of Health and Human Services, Public Health and Human Services, Centre for Disease Control, Atlanta, Ga, USA, 2007.

[22] B. P. Lanphear, R. Hornung, J. Khoury et al., "Low-level environmental lead exposure and children's intellectual function: an international pooled analysis," Environmental Health Perspectives, vol. 113, no. 7, pp. 894-899, 2005.

[23] WHO, Evaluations of the Joint FAO/WHO Expert Committee on Food Additives, (JECFA, Lead: General information, World Health Organisation, Geneva, Switzerland, 2011.

[24] R. A. Wuana and F. E. Okieimen, "Heavy metals in contaminated soils: a review of sources, chemistry, risks and best available strategies for remediation," ISRN Ecology, vol. 2011, Article ID 402647, 20 pages, 2011.

[25] IARC, Monographs on the evaluation of carcinogenic risks to humans, IARC, 2016.

[26] A. C. Ross, C. L. Taylor, and A. I. Yaktine, Eds., Dietary Reference Intakes for calcium and vitamin D, Institute of Medicine (US) Committee to review dietary reference intakes for vitamin $D$ and Calcium, The national Academies Press, Washington DC, USA, 2011.

[27] FAO, Quality of analytical procedures in. Guidelines for quality management in soil and plant laboratories, FAO and ISRIC, Rome, Italy, 1998.

[28] J. Brzezicha-Cirocka, M. Grembecka, and P. Szefer, "Monitoring of essential and heavy metals in green tea from different geographical origins," Environmental Monitoring and Assessment, vol. 188 , no. 3 , article 183, 2016.

[29] N. T. Mahlangeni, R. Moodley, and S. B. Jonnalagadda, "Elemental composition of Cyrtanthus obliquus and Lippia javanica used in South African herbal tonic, Imbiza," Arabian Journal of Chemistry, 2014. 
[30] M. A. Zazouli, A. M. Bandpei, A. Maleki, M. Saberian, and H. Izanloo, "Determination of cadmium and lead contents in black tea and tea liquor from Iran," Asian Journal of Chemistry, vol. 22, no. 2, pp. 1387-1393, 2010.

[31] A. Szymczycha-Madeja, M. Welna, and P. Pohl, "Elemental analysis of teas and their infusions by spectrometric methods," Trends in Analytical Chemistry, vol. 35, pp. 165-181, 2012.

[32] L. Polechońska, M. Dambiec, A. Klink, and A. Rudecki, "Concentrations and solubility of selected trace metals in leaf and bagged black teas commercialized in Poland," Journal of Food and Drug Analysis, vol. 23, no. 3, pp. 486-492, 2015.

[33] W.-S. Zhong, T. Ren, and L.-J. Zhao, "Determination of $\mathrm{Pb}$ (Lead), Cd (Cadmium), Cr (Chromium), Cu (Copper), and $\mathrm{Ni}$ (Nickel) in Chinese tea with high-resolution continuum source graphite furnace atomic absorption spectrometry," Journal of Food and Drug Analysis, vol. 24, no. 1, pp. 46-55, 2016.

[34] N. Blagojević, B. Damjanović-Vratnica, V. Vukašinović-Pešić, and D. Durović, "Heavy metals content in leaves and extracts of wild-growing Salvia Officinalis from montenegro," Polish Journal of Environmental Studies, vol. 18, no. 2, pp. 167-173, 2009.

[35] S. S. AL-Oud, "Heavy metal contents in tea and herb leaves," Pakistan Journal of Biological Sciences, vol. 6, no. 3, pp. 208-212, 2003.

[36] P. Chand, R. Sharma, R. Prasad, R. K. Sud, and Y. B. Pakade, "Determination of essential \& toxic metal and its transversal pattern from soil to tea brew," Food and Nutrition Sciences, vol. 02, no. 10, pp. 1160-1165, 2011. 


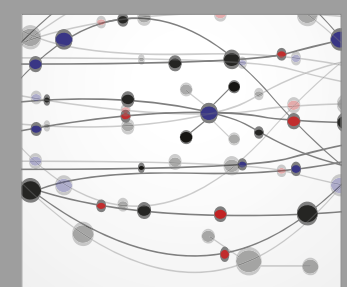

The Scientific World Journal
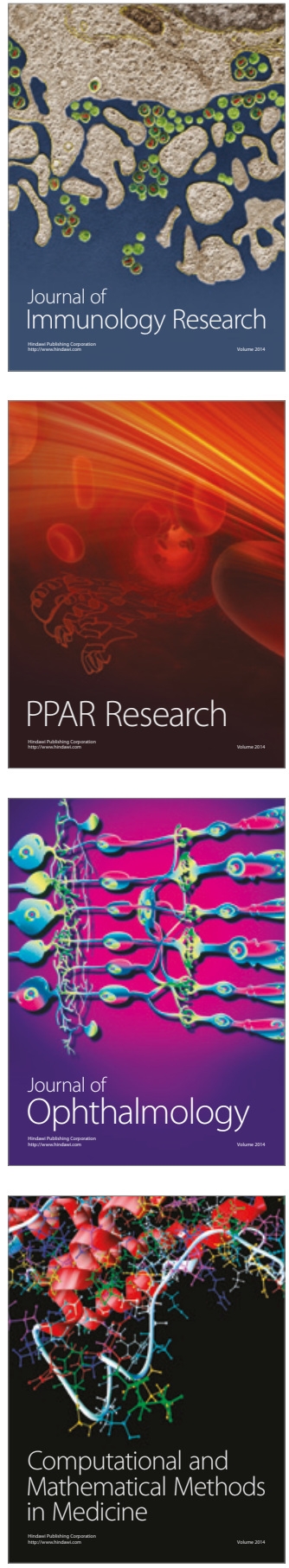

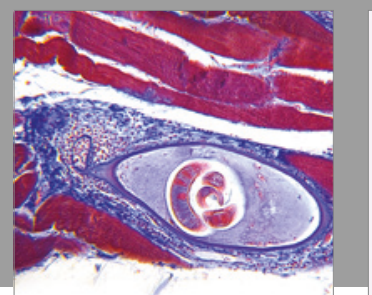

Gastroenterology Research and Practice
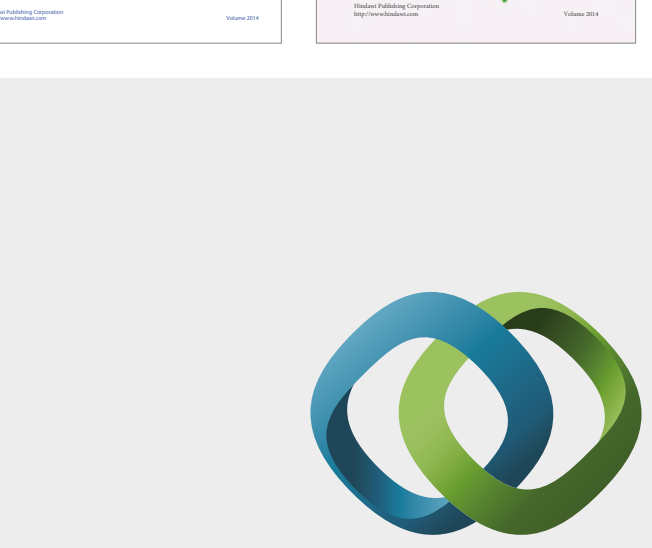

\section{Hindawi}

Submit your manuscripts at

https://www.hindawi.com
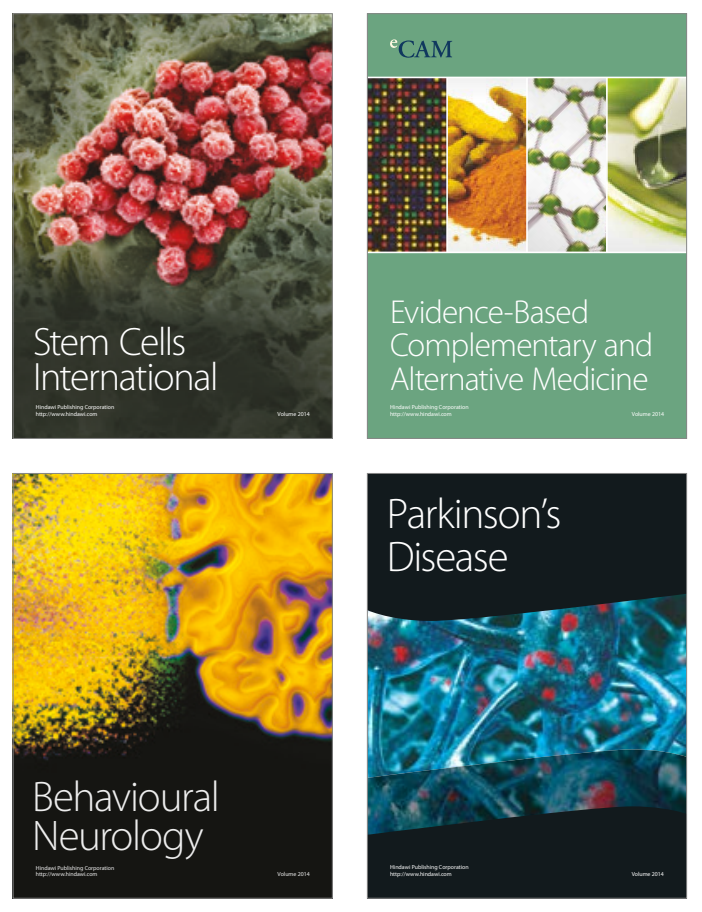
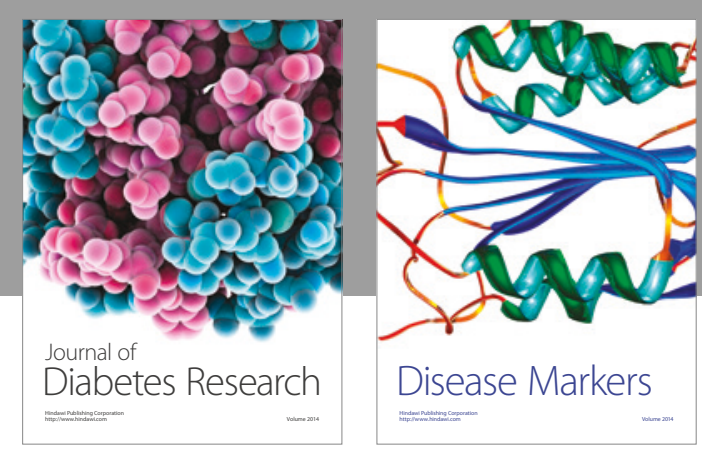

Disease Markers
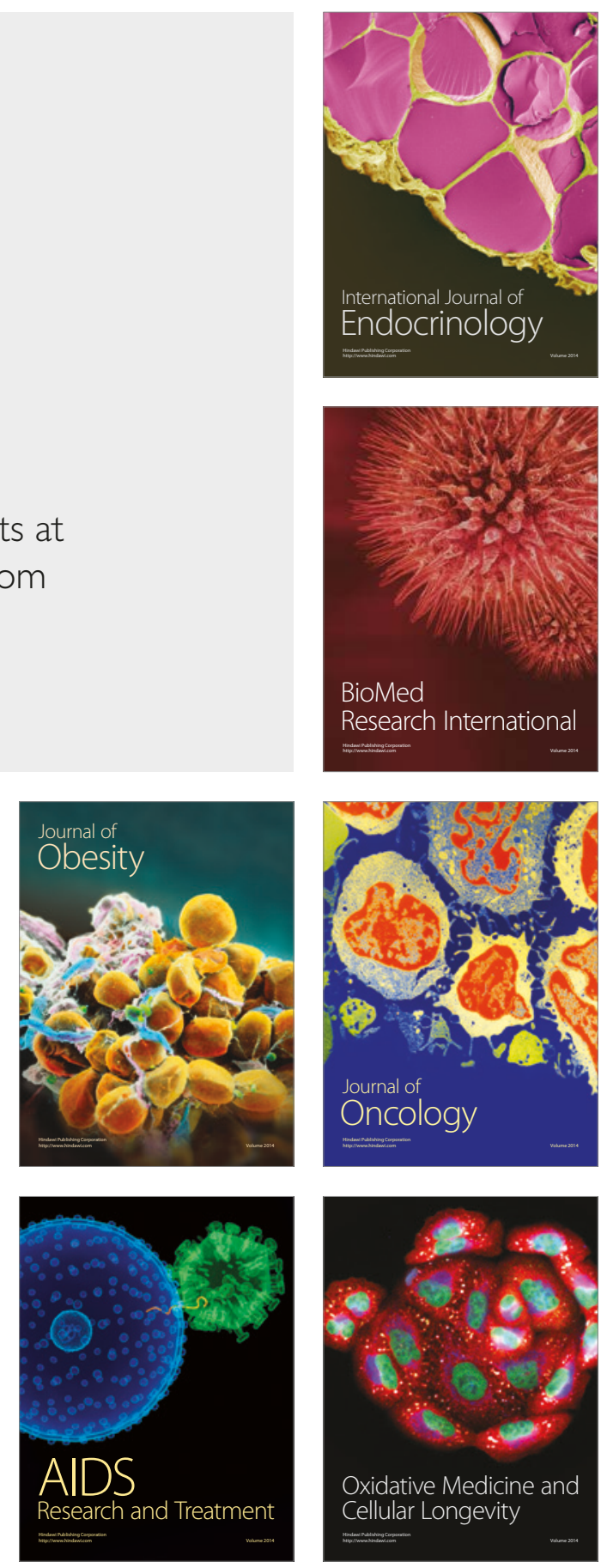